\title{
FEMICIDES: DIFFERENT APPROACHES FROM THE REGIONAL PROTEGTION OF HUMAN RIGHTS
}

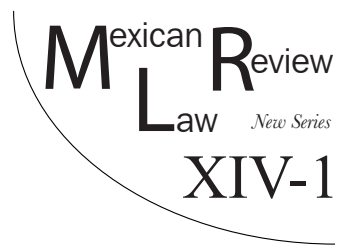

\author{
Isabel Anayanssi Orizaga InZunzA*
}

\begin{abstract}
Since the adoption of the term femicide for gender-based killings of women, the theoretical development and transition of this definition to a legal concept has contributed to the acknowledgment of this phenomenon as the most extreme manifestation of violence against women. In the international sphere, the regional systems of protection of human rights appear as fertile soil for victims of femicide to claim protection. Consequently, the European Court, Inter-American, and the ECOWAS Court of human rights play an important role in the investigation, prosecution, and reparation of femicide in their regions. Nevertheless, through their jurisprudence in the matter, regional courts of human rights have adopted different approaches for femicide. This showes striking differences in the recognition of the phenomenon of femicide, the development of State obligations, and the reparation for victims. The minimalistic approach applied by the European Court in its cases, as well as a single precedent of feminicide studied by the ECOWAS Court, makes us turn the view to the Inter-American Court of Human Rights. Based on its maximalist approach, the Inter-American Court has gone beyond its sister courts to establish a consolidated recognition of the phenomenon of femicide, and to develop in a wider and deeper way the scope of State obligations and reparations on femicide cases.
\end{abstract}

KEYWORDs: Femicide, violence against women, human rights, regional courts of human rights, Inter-American Court of Human Rights.

RESumen: Desde la adopción del término feminicidio para los asesinatos de mujeres por razón de género, el desarrollo teórico y la transición de esta definición a un concepto legal ha contribuido al reconocimiento de este fenómeno como

* Mexican Feminist Lawyer. She obtained her law degree from the Autonomous University of Baja California, Mexico in 2014. She also earned her Masters in Constitutional and Inter-American protection of fundamental rights from the National Autonomous University of Mexico and the Complutense University of Madrid in 2015, and her LLM-Program in International Human Rights Law (cum laude) from the University of Notre Dame in 2020. Email: isabel.orizaga@outlook. 
la manifestación más extrema de violencia contra las mujeres. En el ámbito internacional, los sistemas regionales de protección de los derechos humanos se erigen como un terreno fértil para que las víctimas de femicidio reclamen la protección de sus derechos. En ese sentido, la Corte Europea, la Corte Interamericana y el Tribunal de la Comunidad ECOWAS juegan un papel importante en la investigación, enjuiciamiento y reparación del feminicidio en sus regiones. Sin embargo, a través de su jurisprudencia en la materia, los tribunales regionales de derechos humanos han adoptado diferentes enfoques para el femicidio. Esto evidencia diferencias notables en el reconocimiento del fenómeno del femicidio, el desarrollo de las obligaciones del Estado y la reparación a las víctimas. El enfoque minimalista aplicado por la Corte Europea en sus casos, así como un solo precedente de feminicidio estudiado por el Tribunal de la Comunidad ECOWAS, nos hace volver la mirada hacia la Corte Interamericana de Derechos Humanos. Partiendo de su particular enfoque maximalista, la Corte Interamericana ha ido más allá de sus tribunales hermanos para establecer un reconocimiento consolidado del fenómeno del feminicidio y desarrollar de manera más amplia y profunda el alcance de las obligaciones y reparaciones estatales en casos de feminicidio.

Palabras clave: Feminicidio, violencia contra las mujeres, derechos humanos, cortes regionales de derechos humanos, Corte Interamericana de Derechos

Humanos.

Table of Gontents

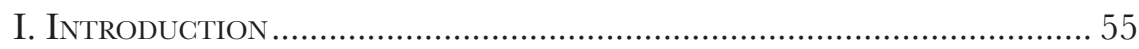

II. Violence Against Women: Femicide ............................................. 56

1. Killing a Woman: A Crime of Passion or Honor?....................... 57

2. Femicide and Feminicide: Putting a Name to a Face? ................. 59

3. What is Femicide and What is Not? .......................................... 61

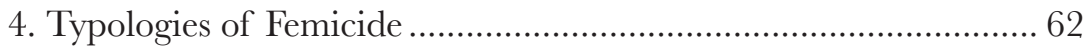

5. From Theory to Law: A Challenge............................................... 64

III. Regional Systems of Human Rights: Three Different

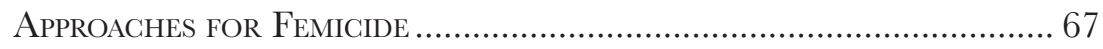

1. The European System of Human Rights.................................. 68

A. The European Cases of Femicide............................................. 69

2. The Inter-American System of Human Rights........................... 73

A. The Inter-American Cases of Femicide .................................. 74

3. Africa: the African System of Human Rights and the Economic Community of West African States Court of Justice.................... 77

A. Case of Mary Sunday v. Federal Republic of Nigeria............. 78

IV. Europe, America, and Africa: Different Stages of Acknowledgement of Femicide? 
2. Making the Problem Visible: Identification of Gender-Based Killings, and Different Kinds of Femicides

3. Maximalist Approach versus Minimal Approach.....

4. The Scope of The State's Obligations.

5. Reparations.

V. Conclusions. 86

\section{INTRODUCTION}

Violence against women and girls or gender-based violence has been deemed by international organizations such as the United Nations ${ }^{1}$ and the World $\mathrm{Bank}^{2}$ as a global pandemic. Hence, considering that approximately fifty percent of the world's population are women, it may be said that gender is not only the most important category of social division but also the main reason for inequity, discrimination, and violence around the globe.

However, within the spectrum of violence that women and girls suffer, the feminicide o femicide ${ }^{3}$ can be considered as the most radical act of violence against them. Feminicide is the murder of a woman or a girl because of their gender, and it can be perpetrated under a variety of circumstances and committed by different individuals, most of them their partners or former partners. But also, feminicide can be perpetrated by individuals that do not have a close relationship with the victim, even some femicides are committed by strangers who kidnap women. The use of the term feminicide or femicide has been recognized as a political way to differentiate the deaths of women because of their gender from homicides. It has led to a better understanding of the dimensions of violence against women, and it has been the beginning of data collection, ${ }^{4}$ policies design, and one of the most important: the claim for justice in the national and international arena.

1 Ending inequality means ending "global pandemic" of violence against women - UN chief, UN NEws (2018), available at https://news.un.org/en/story/2018/11/1026071.

2 Gender-Based Violence (Violence Against Women and Girls), The WorLd BANK (2019), available at https://wrew.worldbank.org/en/topic/socialdevelopment/brief/violence-against-women-and-girls.

3 For this document, the author uses the term femicide or feminicide indistinctly for reasons that will be explained further.

4 The World Health Organization has stated: "Collecting correct data on femicide is challenging, largely because in most countries, police and medical data-collection systems that document cases of homicide often do not have the necessary information or do not report the victim-perpetrator relationship or the motives for the homicide, let alone gender-related motivations for murder (4-6). However, data on the nature and prevalence of femicide are increasing worldwide, illustrated by the following findings from the literature." World Health Organization, Understanding and addressing violence against women, WHO/RHR/12.38 (2012), available at https://apps.who.int/iris/bitstream/handle/10665/77421/WHO_RHR_12.38_eng.pdf? sequence=1. 
At a national level, the asymmetric relations between women and men, the high levels of violence against women, and the lack of effective mechanisms of prevention, investigation, and sanction of the crime of feminicides usually pushes victims to elevate their claims at a supranational level. At that level, and after a long path in their seek of justice, victims usually find an opportunity to be heard within the regional systems of protection of human rights.

Regional systems of human rights have protected and developed a strong platform that can be used by victims of human rights violations to claim justice and reparations. At the same time, their institutions, especially their courts, have become respected and prestigious tribunals lead the agenda of human rights in its regions.

Currently, the most prominent system of protection of human rights is based in Europe, America, and Africa. Each system has its own characteristics, agenda, and concerns according to the region they represent. But all of them are, in theory, a fertile soil where the global phenomenon of feminicide can be addressed.

This article attempts to explore the treatment given to cases related to femicides by the European, Inter-American, and African courts of human rights. The article begins by highlighting the theoretical development of femicide as a specific term for gender-based killings of women and its transition to a legal concept. Part II goes on to stress the importance of the European, InterAmerican, and African Systems of Human Rights in promoting women's rights, and the analysis of the femicide cases studied for each court. Part III explores the similarities and differences between these tribunals' approach in their feminicides cases, their acknowledgment of the phenomenon, as well as the impact of those approaches on the recognition and analysis of the problem of feminicide. Finally, the conclusions point out some areas of improvement of the three tribunals on the analysis of feminicides. But also, the findings will show that, as a part of its maximalist approach, the Inter-American Court has developed the scope of State obligations and reparations in a wider and deeper way as compared to those developments made by the European Court of Human Rights and by the ECOWAS Court.

\section{Violence Against Women: Femicide}

Understanding the phenomenon of discrimination and violence against women involves several explanations and factors that always lead to the same place: a culture of patriarchy that shows the asymmetric relations between gendered beings. Since their birth women and men are assigned specific places and roles in society from which, depending on their economic situation, nationality, race, age, and education, among other categories, they face inequalities and adopt different privileges. In the case of women, the intersection of all those categories combined with gender seems to be always an adverse condition that operates against their rights. 
As a form of discrimination, violence against women has received particular attention from the international community because of the danger it infringes on women's dignity and rights. The international concerns have been established through the adoption of several international instruments whose aim is to prevent, investigate and eradicate that risk. At a regional level, the most important treaty adopted based on violence is the Inter-American Convention on the Prevention, Punishment, and Eradication of Violence against Women, known as the Convention of Belém do Pará. Adopted in 1994, it was the first treaty to establish the right of every woman "to be free from violence in both the public and private spheres". 5

Violence against women englobes, as well as discrimination a wide spectrum of manifestations that can cause physical, sexual, or psychological harm to women. Some of these practices include intimate partner violence, child marriage, human trafficking, sexual violence and harassment, and female genital mutilation, among others. Unfortunately, in most of those cases, violence can escalate to the killing of women, which is in itself a whole field of study.

\section{Killing a Woman: A Crime of Passion or Honor?}

Deprivation of life is one of the most serious attempts against human dignity. According to that reasoning, the right to life is strongly protected by human rights instruments as an essential right. Every second, women as well as men, are deprived of life for different reasons. However, some of those killings are related to the gender of the victim. In the case of killings of women, a considerable amount of them are a result from the fact of the victims being females.

In 2019, the United Nations Office on Drugs and Crime (UNODC) 6 established that from 87000 women that were killed intentionally, almost 60\% were killed by intimate partners and other relatives, which means that every day 137 women are killed by a relative. It does not mean that all of them are gender-related killings, but most of them are. The problem is how to identify those that hide gender motives.

Distinguishing a gender-based killing from the killing of a woman demands an investigation of the circumstances of death ${ }^{7}$ conducted with a gender perspective. It means to identify gender motives that led the perpetrator to kill a woman or a girl. However, in most of the cases, gender-based killings - especially those committed by the intimate partner - are reduced to be called a crime of passion. Society and authorities still consider that

5 OAS, Inter-American Convention on the Prevention, Punishment, and Eradication of Violence against Women "Convention of Belém do Pará" June 9, 1994, article 3.

6 Global study on homicide: Gender-related killing of women and girls, UNODC 10 (2019).

7 Shelah S. Bloom, Violence Against Women and Girls 179 (2008). 
women killings by their husbands, fathers or siblings can be justified for personal, honor, religion issues, or because of women's fault, or as a result of intimate partner violence.

Historically and socially, feminicide has been accepted and regarded as a crime of passion. The question is whether the category of "crime of passion" is helpful to understand the problem. The Legal Information Institute of the University of Cornell cites the definition of a crime of passion as:

A crime committed while in the throes of passion, with no opportunity to reflect on what is happening and what the person is about to do. For example, a husband who discovers his wife in bed with a lover and who attacks and kills the lover in a blind rage has committed a crime of passion. Because the husband has been overcome with emotion, he lacks the specific intent to kill, which is necessary for a conviction of murder. If a jury believes that he acted in the heat of passion, they will convict him only of manslaughter, which does not require an intent to kill. ${ }^{8}$

In the case exemplified, the difference between killing the lover or the wife could be minimal, considering that the conduct of the husband is motivated and can be justified later under the heat of passion. Some of the genderbased killings of women are qualified by authorities as crimes of passion, an action that justifies the conduct of the killer as a state of jealousy or impulsiveness. ${ }^{9}$ This has led in part to romanticize the crime as killing for love, ${ }^{10}$ and at the same time to deny the structural problem that entails the killing of a woman. Hence, qualifying killings of women as crimes of passion is a category that seems to explain and justify the killing from the perspective of the perpetrator.

A similar situation appears when the killing of a woman is considered a crime of honor, as it occurs in the Middle East and North Africa. Honor killings are spread in those regions where religion and society values are used to justify the punishment of women who allegedly have brought disgrace to their families. ${ }^{11}$ For example, women are victims of honor killings for refraining from forced marriage, being the victim of rape, getting divorced, having sexual relationships, or carrying out adultery. ${ }^{12}$ In those cases, killings of

8 Definition, available at https://wrewelaw.cornell.edu/wex/crime_of_passion.

9 Juan Carlos Romero Puga, Del crimen "pasional" al feminicidio, LeTras Libres (2018), available at https://wrere.letraslibres.com/mexico/cultura/del-crimen-pasional-al-feminicidio.

10 Paulina Molina, Domestic Violence in Chile: Calling Out Femicide, NiEman (2019), available at https://nieman.harvard.edu/articles/chile-femicide-is-not-a-crime-melodrama/.

11 Bijan Pirnia, Fariborz Pirnia \& Kambiz Pirnia, Honour killings and violence against women in Iran during the COVID-19 pandemic, 7 The Lancet Psychiatry 60 (2020).

12 Justin J Gengler, Mariam F Alkazemi \& Alanoud Alsharekh, Who supports honor-based violence in the Middle East? Findings from a national survey of Kuwait, JOURNAL OF INTERPERSONAL VIOLENCE (2018). In: Pirnia, supra note 11. 
women are socially accepted under the reasoning that those are punishments in the name of family honor and strong traditions that oblige women to live in a system where they are expected to fulfill specific roles as daughters, wives, and respectable and obedient women.

Both crimes of passion and honor killings are categories that justify and explain violence against women, as a hard consequence for women's abandonment of their duties and also as a provocation for their killers who act as punishers. But the most relevant, the use of those categories as a justification for killings of women denies and impedes to recognize a system of violence and entrenched power relations that create and encourage this kind of demonstration of contempt and authority over women's lives.

Understanding the nature of gender-based killings from a gender perspective, and avoiding to categorize them as simple crimes of passion or honor, is necessary in order to review the circumstances of the death, the relation between the victim and the perpetrator, the motivations of the perpetrator, and sometimes even the context of spread violence against women.

It is necessary to the understanding of the phenomenon, collection of data, and exposure of the subtle differences that can separate the death of a woman from the one resulting from misogyny.

\section{Femicide and Feminicide: Putting a Name to a Face?}

Differentiating gender killings from other women's deaths is a required step to discover the magnitude and the intensity of the problem of violence against women. At the same time, the adoption of a term to call those specific killings seems to be an effort to define the problem, and a political act. It has led to the emergence of the term femicide promoted by Diane Russell, who has explained its origin: "I first heard this word 37 years ago in 1974 when a friend in London told me that she had heard that a woman in the United States was planning to write a book titled «Femicide». I immediately became very excited by this new word, seeing it as a substitute for the gender-neutral word «homicide»". ${ }^{13}$

Through the adoption of this term, as Russell explained above, came the need to identify gender as the reason to distinguish a sex-based hate crime from other deaths. That made visible a specific kind of killings that before that moment seemed to be relegated within the category of homicide. Later in 1976, Russell applied this term in a declaration at the first Tribunal on Crimes Against Women and defined it as "the killing of females by males because they are female". ${ }^{14}$

13 Diana E. Russell, The origin and importance of the term femicide (2011), available at http://wrere. dianarussell. com/origin_of_femicide. html.

14 Jill Radford \& Diana EH Russell, Femicide: The politics of woman killing Xiv (1992). 
In Femicide: The Politics of Woman Killing, which is considered the first study where the concept was developed, femicide was defined as "the misogynist killing of women by men". ${ }^{15}$ The concept of femicide originated within the Anglo-Saxon academy and was taken to Latin America, where it was adopted and adapted to other terms such as feminicide and systemic sexual feminicide. ${ }^{16}$

The usage of femicide to describe the highest level of violence against women was immediately embraced by the feminist movement ${ }^{17}$ in different regions. In Latin America, the term was translated to Spanish as "feminicidio" by the Mexican anthropologist Marcela Lagarde to name the phenomenon of the women of Ciudad Juárez, a series of femicides involving the disappearance of many women, some of whose bodies were found in public spaces during the 90s. However, Lagarde impregnated the concept of feminicide of a strong claim against the State and its role in the prevention, investigation, and sanction of those killings. From this viewpoint, the application of the term feminicide has a political aim to rebuke the impunity and inaction of the authorities and institutions of the State. ${ }^{18}$ According to Marcela Lagarde:

Silence, omission, negligence, and the collusion of authorities in charge of preventing and eradicating these crimes concur in a criminal manner for femicide to occur. Femicide occurs when the State does not provide guarantees to women and does not create conditions of safety for their lives in the community, at home, or in work, transit, or recreational spaces. It happens when the authorities do not perform their functions effectively. If the State fails, impunity is created, crime proliferates and femicide does not end. That is why femicide is a crime of the State. ${ }^{19}$

After the embracement of the term in Latin America, it has been modified to explain specific kinds or particularities of feminicide. For example, Julia Monarrez has coined the term systemic sexual feminicide, who has explained it as:

Systemic sexual femicide is the murder of a girl/woman committed by a man, where all the elements of the unequal relationship between the sexes are found: the generic superiority of the man versus the generic subordination of the

15 Ibid. at XI.

16 Julia Estela Monárrez Fragoso, Feminicidio sexual sistémico: impunidad histórica constante en Ciudad Fuárez, víctimas y perpetradores, 1 Estado \& COMUNES, REVISTA DE POLÍTICAS Y PROBLEMAS PÚBLICOS 88 (2019).

17 See, Magdalena Grzyb et al., Femicide across Europe: Theory, Research and prevenTION (2018).

18 Femicide and feminicide, Guatemala Human Rights Commission, USA Fact Sheet, available at http://wwre.ghrc-usa.org/Programs/ForWomensRighttoLive/factsheet_femicide.pdf.

19 Marcela Lagarde, El feminicidio, delito contra la humanidad, in Feminicidio, Justicia Y derecho. México. Comisión Especial para Conocer y Dar Seguimiento a las Investigaciones Relacionadas con los Feminicidios en la República Mexicana ya la Procuración de Justicia Vinculada 156 (2005). 
woman, misogyny, control, and sexism... [it] has the irrefutable logic of the body of poor girls and women who have been kidnapped, tortured, raped, murdered, and thrown into sexually transgressive settings. ${ }^{20}$

In other regions, femicide has been studied and categorized depending on the reality of each country in which this term has been adopted. The same as in Latin America, the term femicide was adopted in Southeast Asia, where feminists use this concept to refer to the "intentional murder of women by men and of women by other women for men's interests". ${ }^{21}$

In general, naming femicide has permitted to create - with the use of the term - a political flag to face violence against women, and an opportunity to get attention for the government to recognize the problem and to adopt legislative and judicial measures. Regarding the political impact of the adoption of the term "femicide", the creator explained it later:

Just as U.S. Professor Catharine MacKinnon's invention of the new feminist term sexual harassment was necessary before laws against these crimes could be formulated, so I believed that inventing a new term for sexist/misogynist killings of females was necessary for feminists to start organizing to combat these heretofore neglected lethal forms of violence against women and girls. ${ }^{22}$

However, beyond the political impact that the adoption of this term has represented for the movement against gender-based violence - which is relevant in itself-, there are still some discussions about the scope of its definition. For example, some experts have posed questions related to whether the term femicide should also apply to girls' killings and to women killed by other women. ${ }^{23}$ It makes it necessary to elaborate on the characteristics and tools to identify femicide.

\section{What is Femicide and What is Not?}

Femicide is the most extreme manifestation of the power of patriarchy over women's lives. Identifying femicide from a women's murder makes it necessary to identify the gender factor. This is a political action that press to acknowledge that there is a system that allows a person to kill a woman.

20 Fragoso, supra note 16.

21 Walter Dekeseredy \& Linda MacLeod, Counting the pain and suffering: The incidence and prevalence of woman abuse in Canada - Intimate Femicide, in Walter DeKeseredy, Woman abuse: A sociological story (1997). Cited by: Feminicidio, Justicia y derecho. México. Comisión Especial para Conocer y dar Seguimiento a las Investigaciones Relacionadas con los Feminicidios en la República Mexicana ya la Procuración de Justicia Vinculada 139 (2005).

22 Russell, supra note 13.

23 See also, Magdalena Grzyb et al., Femicide across Europe: Theory, research and preVENTION (2018). 
However, it is important to notice that not all the deaths of women are femicides and that is possible to make a difference between them. Russell insists that femicide can be differentiated from the murder of women as well as that "murders that target African Americans can be differentiated from those who are racist from those who are not". ${ }^{24}$

The most important aspect to identify femicide from a non-femicidal murder is that in femicide the victim has been killed by her gender condition: being a woman. This gender condition comes from an entrenched system that establishes power relationships between women and men, establishing the idea that men, husbands, fathers, and even strangers are enough legitimated to dispose of women's lives. Femicidal agent motivation coincides with the idea of the power of men over "the lives and bodies of women to punish them, and ultimately, to preserve social orders of inferiority and oppression". ${ }^{25}$ Under that reasoning, the system creates a violent environment for women where a husband can dispose of his wives' life during an episode of domestic violence; a father can kill his daughter because she disobeyed religious or moral values, or even a stranger can kidnap a woman to rape and to kill her.

Gender-related motives must be a relevant factor for the perpetrator to establish that a woman killing it is, in fact, femicide; otherwise, it is a non-gender-related murder. ${ }^{26}$ According to the OHCHR, in this differentiation it is very important to focus on the presence or absence of gender-related motives that led to or explain the killing of the woman namely: context surrounding the death; circumstances of the death, and the disposal of the body; the history of violence between the victim and the perpetrator; the modus operandi and the type of violations committed before and after death; the family, intimate, interpersonal, community, work and other connections between the perpetrator and the victim; the victim's situation of risk and vulnerability at the time of the killing, and the power inequalities that existed between the victim and the perpetrator. ${ }^{27}$

\section{Typologies of Femicide}

Important efforts have been done to understand and classify femicide according to aspects such as the perpetrator, the relationship between the perpetrator and the victim, characteristics of the victim, or even the motiva-

24 Diana Russel, Definición de feminicidio y conceptos relacionados, in Feminicidio, Justicia y Derecho, México: Giudad de México: Comisión especial para conocer y dar seguimiento a Las investigaciones Relacionadas con los feminicidios en la República Mexicana ya la PROCURACIÓN DE JUSTICIA VINCULADA (2005).

25 Camilo Bernal Sarmiento et al., Latin American model protocol for the investigation of genderrelated killings of women (femicide/feminicide), United Nations (2014).

26 Russell, supra note 24.

27 Sarmiento et al., supra note 25. 
tion of the femicidal agent. However, the author considers that the typology proposed by Diane Rusell — based on other valuable classifications - 28 allows to appreciate a more developed effort of classification. Additionally, the general classification suggested by the United Nations Special Rapporteur on violence against women, its causes, and consequences, as well as by the Latin American Protocol Model for Investigating Violent Deaths of Women gives a general idea of the categorization of this phenomenon.

Diane Russell has established two important typologies of femicide based on previous classifications. The first of them answers recent debates on whether a woman can commit femicide. ${ }^{29}$ Based on Hindu feminists' definition of femicide, ${ }^{30}$ Russell identifies three possible scenarios where women can kill women under a gender motivation. ${ }^{31}$ The first of them refers to women acting as agents of patriarchy, which can include dowry-related murders or mothers-in-law who kill their daughters-in-law. Secondly, women acting as agents of the perpetrator, as partners in crime in femicides related to gangs or honored-based killings. And the third, women responding to interests, which can include jealousy, greed, or even ideological rivalry.

The second typology establishes four kinds of femicides based on the link between the victim and the perpetrator. ${ }^{32}$ One of them is the femicide committed by an intimate partner, which is usually the husband, the boyfriend, the sexual partner, among others. ${ }^{33}$ Another type is called familiar femicide, which can be performed by women siblings. The third type is the one committed by colleagues, friends, or authority figures of the victim, and others. And finally, femicides committed by strangers, which can entail a sexual motivation.

The United Nations Special Rapporteur on violence against women, its causes and consequences, Rashida Manjoo, has suggested another classification of femicides. Under this typology, femicides can be active or direct, which include "killings as a result of intimate-partner violence; sorcery/witchcraftrelated killings; honor-related killings; armed conflict-related killings; dowry-related killings; gender identity- and sexual orientation-related killings; and ethnic- and indigenous identity-related killings". ${ }^{34}$ But also, femicides can be passive or indirect because of deaths "due to poorly conducted or clandestine abortions; maternal mortality; deaths from harmful practices; deaths linked to human trafficking, drug dealing, organized crime, and gang-related activities;

28 See Russelt, supra note 24.

29 See, for example: Shalyah Vail, Consuelo Corradi \& Marceline Naudi, Femicide Across Europe: Theory, Research and Prevention 154 (2018).

30 In Southeast Asia, hindu feminists use this concept to refer to the "intentional murder of women by men and of women by other women for men's interests". RusseLL, supra note 24.

31 Russell, supra note 24, at 140.

32 Russell, supra note 24, at 145.

33 According to the creator of the classification, this kind of femicide is the most popular.

34 UN General Assembly, Report of the Special Rapporteur on violence against women, its causes and consequences, Rashida Manjoo, UN Doc. A/HRC/20/16 (May 23, 2012), para. 16. 
the death of girls or women from simple neglect, through starvation or ill-treatment; and deliberate acts or omissions by the State". 35

In addition to the UN typology, the Latin American Protocol Model for Investigating Violent Deaths of Women establishes other modalities of femicide such as intimate, non-intimate, girl killing, committed by relatives, by connection, systemic sexual femicide, due to prostitution or stigmatized occupations, for human trafficking, transphobic and lesbophobic femicide, racist killing and through genital mutilation. ${ }^{36}$

The invention of typologies of femicides is useful to understand the different scenarios of femicide, but also to build a stronger theory around femicide by widening this field of study. At the same time, it also contributes to normalize the use of the term and to promote the debate in different regions and levels of government. However, defining femicide and taking this term from theory to laws and criminal codes to investigate, to sanction, and to produce data about these crimes is still a challenge.

\section{From Theory to Law: A Challenge}

During the last years, the world has gained awareness on the issue of gender-related killings of women and girls. This has entailed the transition from theory to law. However, it is a very long process of transformation that is still not finished and is not uniform throughout different regions. In this process, three important problems can be identified: difficulties in designing a legal concept of femicide, adoption of laws about femicide, and the impunity of femicide cases despite the categorization of femicide as a crime in laws.

Some have raised the difficulties of transiting from the political category of femicide to a legal concept of femicide that fulfills the requirements of a crime under criminal law. For example, considering feminicide — defined as a State crime in which the State participates by remaining inactive - ${ }^{37}$ as a crime would hardly fulfill the requirements of punishable conduct under criminal law. ${ }^{38}$ According to Alicia Elena Perez Duarte, to establish a crime of femicide in criminal laws, it is necessary to determine the conduct or behaviors that are punishable and to "find ways to integrate the elements of the criminal offense that will set the standard in the investigations and the analyses that must be carried out in criminal proceedings until a conviction is reached". ${ }^{39}$ In sup-

35 Ibid. at para. 16.

36 Sarmiento et al., supra note 25.

37 This concept is the one proposed by Marcela Lagarde.

38 Alicia Elena Perez Duarte N., Feminicidio: Traducción de una categoría política en un concepto jurídico, in Feminicidio, justicia y derecho. México. Comisión Especial para Conocer y dar Seguimiento a las Investigaciones Relacionadas con los Feminicidios en la República Mexicana y a la Procuración de Justicia Vinculada 213 (2005).

39 Id. 
port of this, recent debates about the importance and usefulness of adopting a legal concept - and beyond some positions on whether femicide should be developed as a concept of criminal law or not - consider the importance of establishing femicide as a crime to protect women and to make visible an important social problem. ${ }^{40}$

Beyond those problems, efforts to create awareness among States about the need to punish femicide have included the adoption of important documents such as international treaties, protocols, resolutions, declarations, and others. ${ }^{41}$ Among those efforts, the inclusion of the term femicide in laws within States has become a reality in some regions such as Latin America. Currently, all Latin American countries, except Cuba and Haiti, have passed laws that criminalize femicide. ${ }^{42}$ This is not a coincidence since - according to UN Women - 14 of the 25 countries with the highest rates of femicide in the world are Latin American and Caribbean nations. ${ }^{43}$

However, the considerable extent of impunity in femicide cases in this region has shown that, despite the acknowledgment of femicide in laws and policies, the implementation of laws and protocols as well as the adoption of a gender perspective by the actors involved in investigations is still in the early stages. For example, in Mexico, impunity for the crime of femicide in 2019 was estimated at $51.4 \%$, which implies that about 5 out of 10 femicides were solved. ${ }^{44}$ In Argentina, only $7.5 \%$ of the cases of femicide obtain a condemnation for the perpetrator, ${ }^{45}$ while in El Salvador, only $32.88 \%$ of the cases that occurred during 2018 and 2019 were punished. ${ }^{46}$

40 See also; Alejandra Araiza Díaz, Flor Carina Vargas Martínez \& Uriel Medécigo Daniel, La tipificación del feminicidio en México. Un diálogo entre argumentos sociológicos y jurídicos, 6 REvisTA interdisciplinaria de estudios de géNero de El Colegio de MéXico (2020).

41 According to FemicideWatch, there are some landmarks documents for the strategy against femicide: UNODC, Study on Global Homicide: Gender-related killings of women and girls, 2019; UNGA, Resolution 68/191 (2014) on Taking Action against Gender-related Killing of Women and Girls; Beijing Declaration and Platform for Action; MESECVI, Follow-up Mechanism to the Belém do Pará Convention, 2004; UNGA, Declaration on the Elimination of Violence Against Women 48/104, 1993; Inter-American Convention on the Prevention, Punishment, and Eradication of Violence against Women "Convention of Bélem do Pará", 1994; Latin American Model Protocol for the Investigation of Gender-related Killings of Women (femicide/ feminicide), 2015; Istanbul Convention on Preventing and Combating Violence against Women and Domestic Violence, 2011; and the Vienna Declaration on Femicide 2012.

42 Analysis of Legislation about femicide/feminicide in America Latina and the Caribbean and supplies for a model law, UN WOMEN, at 34.

43 Mireille Widmer, Gendered Analysis of Violent Deaths (2016).

44 Guillermo Raúl Zepeda \& Paola Guadalupe Jiménez, Impunidad en homicidio doloso y feminicidio en México: Reporte 2020, IMPUNIDAD CERo 15 (2020).

45 Esther Pineda, El Femicidio En Argentina (2014-2017): Un Análisis desde La Criminología Cautelar, 4 Revista de la Facultad de Derecho y Ciencias Políticas (Cusco) 107-125 (2019).

46 Mayoría de violencia feminicida ha quedado en la impunidad, ElSALVADOR.com, July 15, 2019, available at https://wrerceelsalvadorcom/eldiariodehoy/mayoria-de-violencia-feminicida-haquedado-en-la-impunidad/621632/2019/. 
The impunity of femicide is strongly related to the prevalence of sexism and gender stereotypes among the personnel who investigate and judge feminicide. According to the National Commission to Prevent and Eradicate Violence Against Women in Mexico:

Investigating a femicide requires special sensitivity on the part of all the people involved in the process: from the expert personnel who review and select the evidence at the crime scene, through the people responsible for its transfer and protection; the doctors who perform the autopsy and the respective forensic analysis; the police personnel in charge of investigating the facts until they reach the judges who pass the sentence. ${ }^{47}$

In the European region, the situation is different from the one in Latin America. A recent study of femicide across 26 countries in Europe has shown that there is not even a wide use of a theoretical concept of femicide nor a legal definition of femicide in criminal laws. ${ }^{48}$ Additionally, official statistics on femicide do not exist in most European countries and feminicide data sources are extremely varied. ${ }^{49}$

In Africa, and particularly in South Africa, femicide has been adopted recently as a theoretical and advocacy concept. Some studies indicate the use of the concept of intimate partner femicide, ${ }^{50}$ and recently, femicide has been the topic for important laws against violence ${ }^{51}$ and for social protests and statements $^{52}$ against high levels of violence against women.

As we have seen, developing awareness about the phenomenon of femicide and translating it from theory into practice is a process still under way. Unfortunately, the lack of uniformity in how the concept is understood and in the inclusion of this crime in laws hinder the ability of the States to guarantee the production of data and also to grasp the dimensions of the

47 Análisis forense y debida diligencia en la investigación del delito de feminicidio, COMISIÓN NACIONAL para Prevenir y Erradicar la Violencia Contra las Mujeres (2018).

48 Magdalena Grzyb et al., Femicide across Europe: Theory, Research and prevention 154 (2018).

49 Id.

50 See, for example: Naeemah Abrahams et al., Intimate partner femicide in South Africa in 1999 and 2009, 10 PLoS MED (2013). Naeemah Abrahams et al., Every eight hours: Intimate femicide in South Africa 10 years later, 2012 South African Medical Research Council Research Brief 1, 4 (2012). Shanaaz Mathews et al., Intimate femicide-suicide in South Africa: a cross-sectional study, 86 Bulletin of the World Health Organization 542-558 (2008).

51 Hassan Isilow, S.Africa announces gender-based violence law, AA (September 7, 2020), available at https://www.aa.com.tr/en/africa/safrica-announces-gender-based-violence-law/1965718.

52 Thuso Khumalo, South Africa Declares "Femicide" a National Crisis, VOA (September 20, 2019), available at https://www.voanews.com/africa/south-africa-declares-femicide-national-crisis. Oluwadamilola Akintewe, Why rape and femicide across Africa is more deadly than Covid-19, OURSECUREFUTURE (August 12, 2020), available at https://oursecurefuture.org/blog/guest-blog-rape-femicideafrica-more-deadly-covid. 
problem. ${ }^{53}$ In most cases, nearly all the initiatives to collect data come from civil society and organizations.

Efforts to deal with femicides are not uniform in all countries and regions, and they are not enough to protect women from gender killings in the local sphere. Even though feminicide is already included in laws and protocols, the refusal of authorities to investigate with diligence and gender perspective are still strong barriers to provide justice for victims. The result is the seeking of justice and arrival of victims to regional systems of human rights, as we will expose later.

\section{Regional Systems of Human Rights:}

Three Different Approaches for Femicide

In the face of a lack of response from State institutions, the global platform created by the international law of human rights is a refuge for those who claim justice, women included. As one of the protagonists of this platform, Regional Systems of Human Rights ("RSHR") are seen by victims as the last opportunity to tell their stories of struggle, to be heard, and to obtain justice and remedies. In response, designed to respond to the needs of specific regions, Regional Systems have the absolute mandate to look after the respect, protection, guarantee, and promotion of human rights in its regions.

Nowadays, Europe, America, and Africa have their RSHR. Within the existent RSHR, regional Courts play an important role in supervising and judging States who have violated human rights. In the case of femicide, and beyond the debates about the difficulties mentioned before about achieving a legal concept in the local sphere, regional Courts oversee whether States parties have protected victim's rights when femicide occurs. After all, femicide is an undeniable severe violation of human rights.

However, the function of regional Courts should not be mistaken for criminal justice. While criminal law investigates and condemns perpetrators of femicide, regional courts of human rights are responsible for declaring responsibility on a State party that breached their international obligations to protect the right to life of women, the right of the families of the victim to access a remedy to investigate femicide, and the right of women not to be subjects of gender-based violence. ${ }^{54}$ For that purpose, a regional court should supervise, for example, whether the State party had enough legal frameworks and policies to prevent, to investigate, and to sanction femicide, or whether it investigated with due diligence a disappearance of a woman that was in danger to be killed.

53 Shalyah Vail et al., Femicide Across Europe: Theory, Research and Prevention (2018).

54 González et al. ("Cotton Field”) v. Mexico, Inter-Am. Ct.H.R. (ser. G) No. 205 (Nov. 16, 2009). 
Having said that, the court's judgments are the product of the last instance in the international arena, and the impact of those decisions can transform the reality of victims in the national sphere. The RSHR represents an opportunity for victims of femicide to claim justice and reparations; however, each system has addressed femicide in different ways. In the following lines, we will explore the main features and significant differences among the femicide cases issued by the three regional courts.

\section{The European System of Human Rights}

Created by the European Convention on Human Rights (ECHR) in 1954, the European RSHR is responsible to ensure human rights in Europe from a regional dimension. After the suppression of the European Commission of Human Rights in 1998, the European System of Human Rights is formed by a full-time court: the European Court of Human Rights (ECtHR).

Even though it happened 26 years after its creation, in 1985 the ECtHR addressed for the first-time discrimination against women in the decision $A b$ dulaziz, Cabales and Balkandali v. UK. ${ }^{55}$ Though slowly, after that decision some others came to increase the current jurisprudence body in the matter. However, the ECtHR has been subjected to criticism because of the low number of decisions in this field despite the crisis of violence against women across the European continent. ${ }^{56}$ According to that, in the period between 1985 and 2017, the ECtHR had issued only 34 cases in which it has found discrimination against women. ${ }^{57}$ The latest number of cases up to December 2019 is $35 .{ }^{58}$ Despite the low number of cases related to women's rights, the ECtHR has had the opportunity to tackle the problem of feminicide. The first one was the leading case of Opuz r. Turkey ${ }^{59}$ that was followed by the cases of Branko Tomašic and others v. Croatia ${ }^{60}$ and Bopkhoyeva v. Russia. ${ }^{61}$

Moreover, one of the most important steps against femicide within this RSHR has been the adoption of the Convention on preventing and combating violence against women and domestic violence, known as the Istanbul

\footnotetext{
55 Abdulaziz, Cabales and Balkandali v. UK, 1985 Eur. Ct. H.R, available at http://hudoc. echr.coe.int/eng? $i=001-57416$.

56 Lisa McIntosh Sundstrom et al., Courting gender Justice 1-27 (2019).

57 Ibid. at 3.

58 This is the latest case issued in 2019: Volodina $v$. Russia, 2019 Eur. Ct. H.R, available at http://hudoc.echr.coe.int/eng? $i=001-194321$.

59 Opuz v. Turkey, 2009-II Eur. Ct. H.R. 107.

60 Branko Tomašić and others v. Croatia, 2009 Eur. Ct. H.R, available at http://hudoc.echr. coe.int/eng? $\mathrm{i}=001-90625$.

61 Bopkhoyeva v. Russia, 2018 Eur. Ct. H.R, available at http://hudoc.echr.coe.int/ eng? $\mathrm{i}=001-180849$.
} 
Convention. It was adopted by the Council of Europe Committee of Ministers in 2011, and it is the second treaty - after the Convention Belem do Pará - that addresses specifically violence against women. One of its contributions is the acknowledgment of domestic violence as an endemic crisis across Europe, ${ }^{62}$ a topic that is strongly involved in the cases of femicide analyzed by the Court, as will be seen below.

\section{A. The European Cases of Femicide}

The cases Opuz v. Turkey, ${ }^{63}$ Branko Tomašic and others v. Croatia ${ }^{64}$ and Bopkhoyeva v. Russia ${ }^{65}$ raise three different scenarios in which femicide can occur. Nevertheless, the cases contain at least three common elements shared among them: a) the victims sustained a close relationship with the perpetrators, they were their intimate-partners or their family in law; $b$ ) the femicide occurred within a domestic violence context, something that has been acknowledged as a generalized problem in Europe; and c) the authorities did not provide appropriate protection to the victims nor investigated their killings under a gender perspective, that is as gender-based killings.

Having said that, it is important to mention that the ECtHR did not use the term of femicide in its jurisprudence, nor did it address the cases as gender-based killings even though they contain some elements that allow us to suspect that the three killings were manifestations of extreme acts of violence against women based on their gender. As we will notice, in one of them, the ECtHR identified that the killing was a product of domestic violence that was not investigated due to gender stereotypes and tolerance of gender-based violence by the State. In the other two, the Court seemed to ignore some gender and contextual elements that had helped the Court in two ways: a) to identify possible gender-violence and gender-stereotypes as the cause of the victim's deaths and as the reason why the authorities did not investigate those killings, respectively, and b) to order the States to conduct investigations of those killings under a gender perspective in the local sphere.

\section{a. Case of Opuz v. Turkey}

This case is considered the first and most important case issued by the ECtHR regarding feminicides. In this case, the perpetrator killed his mother-

62 What is the Istanbul Convention? Who is it for? Why is it important?, CounciL of Europe, available at https://ec.europa.eu/justice/saynostopvaw/downloads/materials/pdf/istanbul-conventionleaflet-online.pdf.

63 Opuz, supra note 59.

64 Branko, supra note 60.

65 Opuz, supra note 61. 
in-law. The facts occurred within a context of domestic violence between the applicant and the perpetrator, who finally shot the mother of the applicant while she was trying to help her daughter to flee the matrimonial home.

Previously, the applicant, as well as her mother, had reported several incidents to authorities, which included physical violence, an attempt to run over the applicant and her mother with a car leaving the mother seriously injured, and an assault in which the applicant was stabbed seven times. ${ }^{66}$ The perpetrator had already threatened his mother-in-law under the justification that she discouraged his wife to return to him, and he wanted to keep his family together. According to the facts, two weeks before the shot, the victims had reported again the risk situation to the authorities, who were already aware of the previous death threats. Nevertheless, the authorities considered that they could not intervene in a "family matter" and did not take protective measures.

The applicant argued that Turkey had failed to fulfill its obligation towards the right to life, the prohibition of torture or inhuman or degrading treatment, the right to an effective remedy, and freedom from discrimination. The Court declared the violation of articles 2, 3, and 14 of the EGHR. ${ }^{67}$ In its analysis, the tribunal stated that the authorities had breached their positive obligation to protect the applicant and her mother and determined that: a) there was a foreseeable risk that the authorities knew about, and it was not avoided; $b$ ) the authorities did not adopt protective measures for the victims, and $c$ ) there was not an effective investigation of the killing, whose criminal investigation extended for more than six years even when the perpetrator had already confessed. All those violations were the result of a general and discriminatory judicial passivity in the State regarding violence against women that contributed to the execution of the gender-based killing.

In general, the Court also noticed that domestic violence was tolerated by the authorities, who did not investigate women's complaints and assumed the role of mediator while tried to convince them to return home and drop their complaints. In this case, femicide was executed within a complex situation of gender violence that was followed by a lack of prevention and adoption of protective measures for the victims by the State party. The State party tolerated the situation under stereotypes and beliefs that the violence suffered by the victim was a family issue. The applicant and her mother had been victims of gender-based violence and even after the femicide was perpetrated it has been kept unpunished.

Concerning reparations, the Court ordered the State to pay monetary compensation to victims for non-pecuniary damages and legal aid.

66 The perpetrator had been convicted for those offenses with a three-month prison sentence and a fine.

67 Opuz, supra note 59, at para. 35, 36. 


\section{b. Case of Branko Tomašic and others v. Croatia}

In this case, the femicide was perpetrated by the intimate partner, who shot his wife and his son dead, before committing suicide. According to the facts, the couple had been living in the parent's house of the victim, but after some discussions with siblings, the perpetrator moved out. The victim and her daughter continued living with her parents, and during that time, she alleged on several occasions that the perpetrator had come to her home or had called her to say he was going to kill her and their daughter with a bomb unless she agreed to come back to him. ${ }^{68}$ These threats continued for almost two years. The victim filed a criminal proceeding, and he was sentenced to five months' imprisonment and, as a security measure, was ordered to have compulsory psychiatric treatment. ${ }^{69}$

However, once he served his sentence, he shot her partner and his daughter and committed suicide by turning the gun on himself. The ECtHR declared violations to article 2 of the ECHR after an effective investigation of the killings of the victims and a lack of adoption of "domestic laws which protect the right to life". ${ }^{70}$ Reaching its decision, the Court noticed three factors: a) the authorities were aware of the seriousness of the threats made by the perpetrator to the victim; $b$ ) during the criminal proceedings, the authorities had failed to order and carry out a search of his premises and vehicle even when they knew about the threats to attack the victim with a bomb; and c) the perpetrator did not receive psychiatric treatment in prison nor after his release. According to the tribunal, these elements contributed to the lack of adoption of protective measures for the victim and her daughter.

Another relevant aspect of this case is the fact that the Court did not consider these killings were based on gender violence. In this regard, it is important to analyze the intimate relationship between the perpetrator and the victim from a gender perspective. As the facts indicate, the threats against the victim were made in a context of a discussion where the perpetrator exercised pressure on her to come back to him, which makes evident an asymmetric power relationship in which the perpetrator felt that he had the right to own the victim. Nevertheless, the Court seemed concentrated on the analysis of the psychiatric disorders of the perpetrator without taking into consideration that gender-based violence and psychiatric problems are, in fact, very related.

Again, the ECtHR did not mention a gender element nor femicide at all although there were key elements in the facts to establish that it was femicide. For example, there was an intimate relationship between the perpetrator and

68 Branko, supra note 60, at para. 5.

69 According to the judgment, the documents submitted showed that his treatment in prison had consisted of conversational sessions with prison staff, none of whom was a psychiatrist.

70 Ibid. at 18. 
the victim, the killings occurred after the victim's refusal to come back to the perpetrator, and the perpetrator had the motivation to kill her unless she accepted to continue their relationship.

Regarding reparations, the Court ordered the State to pay monetary compensation to victims for non-pecuniary damages.

\section{c. Case of Bopkhoyeva v. Russia}

This case is about femicide committed by the family-in-law of the victim. The applicant, who had been in a coma since 2010, was represented by her mother. According to the case, after she was abducted by $\mathrm{S}$ who intended to marry her, the victim's mother opposed the marriage, and S's relatives took the applicant back to her mother's house, but the next day, the victim was obliged by her deceased father's siblings to go back because the marriage had been consummated. She was kept living with S's family home as his wife, where she was forced to live in a locked room without being able to communicate with people outside. During that time, she was poisoned by her motherin-law. She visited the municipal hospital on diverse occasions until she was diagnosed with a vegetative state and was released to her mother's care, ${ }^{71}$ who complained to the local police department and prosecutor's office that his daughter had been obliged to live with S's family in "inhuman conditions which led to a deterioration of her health".

Nevertheless, after several complaints and appeals, the authorities refused to open criminal proceedings against S's family and repeatedly dismissed the complaint. The argument not to open a criminal investigation was that the victim's medical case file did not contain information accounting for the cause of her medical condition.

The ECtHR declared violations to article 2 of the ECHR because the complaint containing allegations of ill-treatment suffered by the victim had been kept pending by local authorities for almost 8 years. According to the tribunal, there was a non-effective investigation of the charges of attempt to murder and damages to health. The State party acknowledged the failure of authorities to conduct an effective investigation.

In its analysis, the Court determined that as a part of the positive obligation, the State had a duty to establish a "legislative and administrative framework to provide effective deterrence against threats to the right to life". ${ }^{72}$ In the Court's view, the State failure to start criminal prosecution of the most probable direct perpetrators undermined "the effectiveness of the criminal-law mechanism aimed at prevention, suppression, and punishment of unlawful killings". The State had failed its obligation to conduct an effective investigation.

71 Bopkhoyeva, supra note 61, at para. 2, 3.

72 Ibid. at para. 34. 
The ECtHR did not go deep into the probable reasons why in the local sphere authorities refused to begin a criminal investigation. According to the local procedures filed by the victim's mother, an appellate court determined that the investigator who refused to start a criminal investigation had failed to question some important witnesses and to establish the cause of the applicant's condition. For example, the mother had previously informed the local police department that the victim had been repeatedly beaten up and deprived of her liberty by her family-in-law.

In this case, although the ECtHR ordered the State to initiate a criminal investigation, it is problematic that the Court did not identify a possible pattern of gender-based violence in this case nor order the State to investigate with a gender perspective. In our opinion, it is possible to notice some elements that - considered under a gender perspective - would allow suspecting that the victim suffered a femicide attempted by her mother-in-law. This could be labeled as femicide committed by a woman. The victim was abducted by S, who abandoned her with his family before moving to another town. She was deprived of her liberty, locked inside a room with no opportunity to communicate with her family and was poisoned by her mother-inlaw. It is hard not to see that the circumstances she lived were embedded in entrenched relations of power that deprived her of her right to life.

As reparations, the Court ordered the State to pay monetary compensation to victims for non-pecuniary damages.

\section{The Inter-American System of Human Rights}

Being second in creation - by the American Convention on Human Rights (ACHR - - and integrated by the Inter-American Commission on Human Rights and the Inter-American Court of Human Rights (IACtHR), the InterAmerican System of Human Rights adopted the protection and promotion of women's rights in the American region as one of its goals. As part of its legal framework, the Inter-American Convention on the Prevention, Punishment, and Eradication of Violence against Women, known as the "Belem do Pará Convention" was adopted in 1994. This treaty was the first instrument in the world that focused on the problem of violence against women, ${ }^{73}$ and is a key instrument used by the IACtHR in femicide cases.

The IACtHR has ruled in several cases related to violence against women. Its first judgment in the matter was in 2006 on the Case of the Miguel Castro Castro Prison v. Peru, ${ }^{74} 30$ years after the Court's creation, and since that moment,

73 Inter-American Convention on the Prevention, Punishment, and Eradication of Violence against Women (Belem do Pará), Mechanism to the Belém do Pará Convention (MESECVI), OAS, 3, available at https://rererc.oas.org/en/mesecvi/docs/Folleto-BelemdoPara-EN-WEB.pdf.

74 Miguel Castro Castro Prison v. Peru, Inter-Am. Ct.H.R. (ser. C) No. 160 (Nov. 25, 2006). 
it has decided on 15 cases $^{75}$ of gender-based violence. Three of them have addressed feminicide: Case of González et al. ("Cotton Field") v. Mexico, ${ }^{76}$ Case of Véliz Franco et al. v. Guatemala ${ }^{77}$ and Case of Velásquez Paiz et al. v. Guatemala. ${ }^{78}$

In their femicide judgments, the Court has widely adopted the concept of femicide and promoted the use of the term in the region. Moreover, through femicide cases, the Court has obliged States to acknowledge the problem of feminicide and to create legislation frameworks to prevent, to investigate, and to sanction it. As we will see below, when studying femicide cases the IACtHR has focused on three important aspects: a) the duty of prevention and due diligence during investigations; b) the eradication of gender stereotypes as barriers to femicide investigations, and c) comprehensive reparations for victims.

\section{A. The Inter-American Cases of Femicide}

\section{a. Case of González et al. ("Cotton Field") v. Mexico}

This case is the most emblematic gender-related case issued until now by this tribunal. The applicants claimed international responsibility for the disappearance and murder of three women in Mexico. Their bodies were left by the perpetrators in a cotton field in Chihuahua, Mexico, and their families' claims for justice were ignored by the State authorities despite the relationship of those killings with the "existence of a pattern of gender-related violence that had resulted in hundreds of women and girls murdered"79 called "Dead women of Juarez" (in Spanish "Las muertas de Juárez").

The IACtHR declared the violation of different aspects of articles 4, 5, 7, 8, and 25 of the ACHR, as well as articles 7, b) and c) of the Convention of Belem do Pará. In its analysis, the Court determined that the three feminicides "were gender-based and were perpetrated in an acknowledged context of violence against women in Ciudad Juárez". ${ }^{80}$ Concerning the duty of prevention, the tribunal observed the performance of the State for two moments (two-moment standard): before the disappearance of the victims and before the discovery of their bodies. The Court determined that, even though the State could not respond unlimitedly for the disappearance of any women or girl (the first moment), the State had a rigorous duty - once it became aware

75 The most recent case is: Case Guzmán Albarracín y otras v. Ecuador, Inter-Am. Ct.H.R. (ser. G) No. 405 (Jun. 24, 2020).

76 González et al. ("Cotton Field”) v. Mexico, Inter-Am. Ct.H.R. (ser. G) No. 205 (Nov. 16, 2009).

77 Véliz Franco et al. v. Guatemala Inter-Am. Ct.H.R. (ser. G) No. 277 (May. 19, 2014).

78 Velásquez Paiz et al. v. Guatemala Inter-Am. Ct.H.R. (ser. C) No. 307 (Nov 19, 2015).

79 González et al., supra note 76 at para. 2.

80 Ibid. at para. 231. 
of the disappearance of a woman - to seek the victims alive, which included investigating with due diligence considering the "real and imminent risk that the victims would be sexually abused, subjected to ill-treatment and killed". ${ }^{81}$

Moreover, the Court highlighted how gender stereotypes negatively impacted the investigation of the disappearances and death of victims. The tribunal noted that authorities in charge of investigation "made light of the problem and even blamed the victims for their fate based on the way they dressed, the place they worked, their behavior, the fact that they were out alone, or a lack of parental care". ${ }^{82}$

Concerning reparations, and in line with its concept of "integral reparation"83 the tribunal ordered important measures of non-repetition such as a comprehensive, coordinated, and long-term policy and programs to prevent and investigate cases of violence against women; standardization of protocols and legislation to combat feminicides; pieces of training with a gender perspective for authorities, among others.

\section{b. Case Veliz Franco et al. v. Guatemala}

The case is related to the disappearance of María Isabel, 15 years old, and the finding of her body. Her mom reported the disappearance, but authorities required her to wait the official term to report her daughter as a missing person. One day later, the body of the victim was found. Diligences to investigate her murder namely a pathology test to find out if she had been raped were not performed. The investigation was conducted with gender stereotypes about the social reputation and behavior of the victim. The Court emphasized that the killing of María Isabel was part of a "violent context" that affected women during the 2000s. In this period not only the number of women killings increased but also the cruelty of the murders that included in some cases severe sexual abuse and mutilation. ${ }^{84}$

The IACtHR found violations to different aspects of articles 1, 4, 5, 19, 24, 8, and 25 of the ACHR, and articles 7, b) and c) of the Convention of Belém do Pará. Throughout the analysis of the case, the tribunal determined that the State had not fulfilled its duty to prevent the murder of the victim. Particularly, considering the duty of prevention (before the disappearance of the victim and before the discovery of her body), the Court noted that when the State became aware that the victim had disappeared (second moment), it did not conduct an immediate and diligent investigation. ${ }^{85}$ On the contrary, the Court determined

81 Ibid. at para. 282, 283.

82 Ibid. at para. 154.

83 Ibid. at para. 450.

84 Véliz et al., supra note 77, at para. 68.

85 Concurring opinion of Judge Eduardo Ferrer Mac-Gregor on the case of Véliz et al., supra note 76 , at para. 25. 
that gender stereotypes had a "negative influence on the investigation of the case, insofar as they transferred the blame for what happened to the victim and her family members, closing other possible lines of investigation into the circumstances of the case and the identification of the perpetrators". ${ }^{86}$

Concerning reparations, and following its previous case, the tribunal ordered several measures namely requesting to enhance the institutional capacity to combat impunity in cases of violence against women, adopting public policies and institutional programs to eliminate discriminatory stereotypes, and public apologies, among others.

\section{c. Case of Velásquez Paiz et al. v. Guatemala}

In this case, the State was declared responsible for the lack of protection of the life and personal integrity of Claudina Isabel Velásquez Paiz. Her disappearance was reported by her parents, but the authorities asked them to wait at least 24 hours to initiate an investigation. In spite of the awareness of the authorities about Claudina's disappearance and the context of violence against women, the State did not adopt enough measures to seek and protect her. Her body was found one day after her disappearance with signs of extreme sexual violence ${ }^{87}$ but her death was not investigated properly because she was categorized "as a loose woman" due to the place where her body was found, her clothes and piercings, as well as to the fact that she was wearing sandals.

In its analysis, the Court pointed out the duty of States to conduct a diligent investigation under a gender approach attending to the context of violence against women and the imminent risk for the victim, which was known by the State when the parents informed the disappearance of the victim. Particularly, it considered that in cases like this "the prompt and immediate action of the police, prosecution and judicial authorities is essential, ordering prompt and necessary measures to discover the victim's whereabouts". 88

Concerning stereotypes and the categorization of the victim, the tribunal determined that authorities had acted following gender stereotypes that hinder the execution of a proper investigation. Under this reasoning, the Court remarked that the presumptions made by authorities in categorizing a victim of feminicide as a gang member or a "loose woman" reinforce the stereotypical idea that those women are not "considered sufficiently important to be investigated, while also making the woman responsible for or deserving of being attacked". ${ }^{89}$ In this case, the Court mentioned three important aspects

\footnotetext{
86 Véliz et al., supra note 77, at para. 213.

87 Velásquez Paiz et al., supra note 78 at para. 1.

88 Ibid. at para. 122.

89 Ibid. at para. 183.
} 
regarding the consequences resulting from a lack of gender approach in the criminal investigation of a feminicide. ${ }^{90}$

As in its previous cases, the Court ordered several measures of reparation such as educational programs on non-discrimination and violence against women, institutional strengthening for the investigation of cases of violence against women, and policies, among others.

\section{Africa: the African System of Human Rights and the Economic Community of West African States Court of Justice}

Africa has several regional platforms for ensuring human rights, such as the African RSHR and the Economic Community of West African Court of Justice (ECOWAS Court). The African RSHR, formed by the African Commission and African Court on Human and Peoples' Rights, has powerful instruments to protect women's rights. Some of them are the Banjul Charter and the Protocol to the African Charter on Human and People's Rights on the Rights of Women in Africa, called Maputo Protocol. Nevertheless, the African RSHR has been silent about feminicide in the decisions and jurisprudence.

On the other hand, the ECOWAS Court seems to be the leader in this topic. As the judicial institution of the Economic Community of West African States, the ECOWAS Court was empowered to address cases of human rights violations in 2005. It was just the beginning of the journey of the incursion of a regional court into the realm of human rights. Some years after, and despite some doubts about its mandate and suitability, ${ }^{91}$ the ECOWAS Court has taken advantage of the African RSHR in gender topics during the last years. ${ }^{92}$ In 2018, the ECOWAS Court delivered its judgment on the case of Mary Sunday v. Federal Republic of Nigeria that - according to the media - 93 is one of the most important decisions for the promotion of accountability

90 Ibid. at para. 197.

91 Solomon T. Ebobrah, Critical Issues in the Human Rights Mandate of the ECOWAS Court, 54 Journal of African LaW 1, 1-25 (2010).

92 In 2017, the ECOWAS Court delivered a judgment about vagrancy laws that targeted female sex workers. Dorothy Chioma Njemanze \& 3 Ors v. Federal Republic of Nigeria, ECOWAS Court, ECW/CGJ/JUD/08/17 (2017). Currently, this tribunal is analyzing a case related to a government ban that does not allow pregnant girls to go to school. Sierra Leone: Amnesty International joins legal challenge against a government ban on pregnant girls attending school, Amnesty International (2019) available at https://wrerw.amnesty.org/en/latest/ news/2019/06/sierra-leone-amnesty-international-joins-legal-challenge-against-government-ban-on-preg nant-girls-attending-school/.

93 Siobhan Airey, Landmark decision in the first case of domestic violence brought to ECOWAS Community Court of Fustice (ECCF) (Ruling ECW/CCF/APP/26/15, 24th fanuary 2017), INTLAWGRRLS (2017), available at https://ilg2.org/2017/02/19/landmark-decision-in-first-case-of-domestic-violence-bro ught-to-ecowas-community-court-of-justice-eccj-ruling-ecwccjapp2615-24th-january-2017/. 
for women's human rights violations in Africa. This case involves domestic violence in Nigeria. ${ }^{94}$

\section{A. Case of Mary Sunday v. Federal Republic of Nigeria}

This decision has been described as a "historic milestone" 95 for the promotion of the protection of women's rights, as well as an important step towards the recognition of the violence against women as a violation of human rights. The claim of this case is based on the domestic violence suffered by Mary Sunday. His fiancé, who was a policeman, beat her during an argument. She tried to escape the beatings and ran to a neighbor's house, but her fiancé followed her and "was able to force his way into the kitchen and poured a burning stove with a cooking pot of stew on it on Mary Sunday's head and body, setting her on fire". 96

The victim claimed, among others, gender-based discrimination and violations of her right to a remedy. Concerning discrimination, the Court refused the victim's allegations and determined that the facts belonged to the private or family sphere and that domestic violence could not be connected to the State participation. The Court remarked that facts on which the Court was invoked were subject to national criminal courts and involved a purely individual and personal responsibility.

The representation of the victim argued that the State had violated the right to a remedy and the right to dignity. According to the claim, the police closed the investigation under the conclusion that it had been an accident, and the facts had occurred in a different way than that related by the victim. The police supported that the victim had accidentally burned herself with the contents that she tried to pour over her fiancé. According to this, the tribunal stated that "given the gravity of the events involving a police officer and the divergence of versions supported by the parties involved, the police should have refrained from drawing definitive conclusions on the case and content themselves with referring the case and the parties to the competent courts to be pronounced". ${ }^{97}$

As we can observe, the Court refused the claims of the victim regarding gender-based discrimination. This determination was established because the Court considered that the episode of domestic violence suffered by the victim - which can be cataloged as an attempt of femicide - had a private nature in which the State could not be involved.

94 Mary Sunday $v$. Federal Republic of Nigeria, ECOWAS Court, ECW/CCJ/JUD/11/18 (2018).

95 Siobhan Airey, supra note 93.

96 IHRDA \& WARDC On Behalf of Mary Sunday v. The Federal Republic of Nigeria (Mary Sunday Case), IHRDA (2015), available at https://wwre.ihrda.org/2015/12/ihrda-wardcon-behalf-of-mary-sunday-v-the-federal-republic-of-nigeria-mary-sunday-case/.

97 Ibid. at 8. 
Nevertheless, the Court also did not go deep into the reasons why the police closed the investigation and supported the version of the fiancé while, at the same time, it ignored the claims of the victim. In this line, the tribunal missed some elements that could have helped to corroborate if the police closed the investigation acting under the tolerance of domestic violence or gender stereotypes. Particularly, it is taking into consideration that domestic violence is in most countries a problem that is tolerated and ignored by authorities when victims try to complain.

Concerning reparations, the tribunal ordered the State to pay compensation to the victim for damages.

\section{Europe, America, and Africa: Different Stages of Acknowledgement of Femicide?}

As we observed in the previous chapter, the RSHR offers its platforms to victims of gender-based killings to raise their cases and to obtain justice and reparations from States. Nevertheless, each Court has its approach and, in some cases, their approaches to women's killings do not necessarily coincide with the theoretical and legal development of the concept. Some of them do not consider them as gender-based killings and, as the ECtHR and the ECOWAS Court, some do not even use the term femicide for gender-based killings, for example.

The aim of this chapter is to analyze the status of the acknowledgment of femicide as a phenomenon in the RSHR, as well as some of the implications of the different approaches of gender-based killings by the ECtHR, the IACtHR, and by the ECOWAS Court. This includes to identify different aspects: a) the adoption of the term, $b$ ) the identification of women's killings as gender-based killings and the different kinds of femicides, $c$ ) the way in which the maximalist approach of the IACtHR vs. the minimalistic approach of the ECtHR contribute to establish the obligations of States in cases of femicide and to promote awareness of femicide in their regions, and $d$ ) the transformation of local realities through reparations for victims.

\section{Three Regions: Different Names but the Same Phenomenon}

As we stated at the beginning of this document, the adoption of the concept of femicide as a political flag but also as a means to name and to define a problem is an important point to discuss, especially when gender-based killings of women is a common problem in the globe. In this regard, the IACtHR is the only regional court that acknowledges gender-based murders of women as femicides. Since its first case, the Court recognized the usage of the term by the victims and experts who qualified the phenomenon of Ciudad Juárez as 
femicides ${ }^{98}$ and, in its following cases, the Court has also considered that the term feminicidio has been incorporated to the Spanish Dictionary by the Spanish Royal Academy. ${ }^{99}$ In comparison with the ECtHR and the ECOWAS Court, which do not use the concept at all, this recognition and usage of the term by the IACtHR can be also understood as a transition process of the concept from theory and advocacy to international law. The fact that the IACtHR has adopted and used the concept of femicide has contributed to consolidate the term in the region, and to compel the States of the region to consider this topic in their agendas.

The adoption of this term by a regional court entails a clear understanding of the fact that not all the women murders can qualify as gender-based killings, but that the root of femicide is an extreme manifestation of hate against women. In the future, it would be desirable to have a uniform use of the term in regional courts of human rights to globally understand the phenomenon and to create strategies to understand, analyze, and eliminate it.

However, although the adoption of the term by a Court is important, this is just one of several actions through which the regional Courts can contribute to the elimination of femicides, as we will see below.

\section{Making the Problem Visible: Identification of Gender-Based Killings, and Different Kinds of Femicides}

Beyond the adoption of a specific term to refer to gender-based killings, the identification of a gender-based killing from a non-related-gender killing is an important step to make femicide visible. In this regard, the IACtHR is at this moment the most progressive court before the ECtHR and the ECOWAS Court. This may be because this Court has had the opportunity - through the cases that have reached the system - to study the specific contexts of violence against women that prevail in Mexico and in Guatemala, where advocates and academia have pushed the topic to the international sphere, but also because the IACtHR has also been proactive to identify the specific problematic of gender discrimination. This tribunal has been consistent in the treatment of sexual femicides ${ }^{100}$ concerning identifying the cause of femicides, the duties of States as well as the reparations for victims.

However, the ECtHR has not given the same treatment to its cases. This court has barely referred to gender-based murders, even when the three cases previously analyzed contain elements to consider them as gender-based killings. In this sense, which is a very clear example of femicide, the Court high-

98 González et al., supra note 76 at para. 137.

99 Concurring opinion of Judge Eduardo Ferrer Mac-Gregor on the case of Véliz et al., supra note 76 , at para. 2.

100 Celeste Saccomano, The causes of feminicide in Latin America, 24 StUdent PAPER SERIES (2015). 
lighted the issue of gender-based discrimination against women as the origin of the murder of the victim's mother in the Case of Opuz v. Turkey. However, in the following cases, Branko Tomašić and others v. Croatia and Bopkhoyeva v. Russia, the Court focused on the mental health diseases of the perpetrator and the lack of an investigative process of the attempt of murder of the victim, respectively. These two cases represent different kinds of femicide according to the typologies of femicide. The first one was an intimate femicide committed by the husband who also suffered a mental disease, and the second one was attempted by the mother-in-law of the victim. Unfortunately, the tribunal missed the opportunity to make visible that even when those crimes occurred in different scenarios, they share the element of discrimination against women.

Something similar occurred with the case analyzed by the ECOWAS Court. In this case, the fiancé of the victim attempted to kill her because of a domestic violence context, and later the police refused to hear the claims of the victim and denied her access to a remedy for the investigations of the facts. Those elements could help the Court to identify that the main problem of the case was violence against women. Nevertheless, the Court decided there were no elements to address the gender discrimination claims of the victim, considering that domestic violence was, in fact, a family matter.

Moreover, the striking differences in the way in which the three tribunals have tackled women's murders could be also related to the use of gender perspectives among judges. It is important to mention that to identify femicide different from a non-gender-related killing, a gender perspective is a necessary tool which is helpful to keep in mind how power relationships among women and men must be taken into consideration when analyzing a woman murder committed by her intimate partner or siblings. In the following years, it would be helpful if regional courts adopt the gender perspective as a necessary tool to improve their capacity to evaluate in a proper way a case of femicide.

\section{Maximalist Approach versus Minimal Approach}

In the case of femicide and the impact of regional courts in its acknowledgment among countries, the approach taken by a tribunal - in this case by the ECtHR, the IACtHR, and the ECOWAS Court - takes on relevance because its judgments will be addressed to a country but will speak to a whole region. According to literature, "a court dealing with human rights cases may take a more minimalist or maximalist approach to adjudication" 101 depending on how far the tribunal can reach in each case. A minimalistic approach entails issuing a brief judgment that refrains from comments and detailed

101 Álvaro Paúl, Decision-Making Process of the Inter-American Court: An Analysis Prompted by the in Vitro Fertilization Case, 21 ILSA J. INT'L \& CoMP. L. 102 (2014). 
evidence, only referring to the main issue of the case. ${ }^{102}$ In that sense, it can be said that the ECtHR applies a minimal approach over the cases when it is diligent in the establishment of responsibility of a State without analyzing every branch or detail of the case. ${ }^{103}$

The ECtHR is known for its minimalistic approach. On one hand, in its first and leading case Opuz v. Turkey about gender-based killings, it can be said that the tribunal adopted a moderate position between being maximalist or minimalist. Even though the court did not identify the gender-based killing of the case as femicide but as a result of domestic violence, the ECtHR went deep into the study of the facts and the context of domestic violence in Turkey. ${ }^{104}$ It took into consideration reports concerning domestic violence and the situation of women in Turkey and cited previous judgments of the IACtHR and resolutions of the Committee on the Elimination of All Forms of Discrimination Against Women about gender-based violence. Moreover, it established responsibility on the State for violations of the rights to life, to not to be subject of torture or to inhuman or degrading treatments, and to not to be discriminated against, and it briefly ordered compensations for damages.

In its following two cases, however, the ECtHR has applied a minimalist approach. ${ }^{105}$ As it can be observed in the judgments for cases Branko Tomašić and others v. Croatia and Bopkhoyeva v. Russia, the analysis is very brief and focused only on determining the responsibility of States by the facts. The tribunal has not even established a connection between the deaths and affectations to the victims and gender-based crimes, and therefore, it has not been considered essential to study in detail the context of the situation of women in the denounced countries. For these reasons, this Court has not consolidated a strong jurisprudence that can be cited as a reference on the matter.

On the other hand, the aim of the IACtHR to analyze every detail to establish abstract rules in cases shows the maximalist approach adopted by this Court. ${ }^{106}$ Particularly, its case González et al. ("Cotton Field") v. Mexico is an example of the work of the Court to analyze in detail every aspect of the case and to respond to every claim raised by victims. This judgment is an extensive document that is a rich source of references to experts' opinions, international standards, and a meticulous study of the facts and the sequence of State actions. The echo of the document on the region is still producing several discussions and academic products on the matter. ${ }^{107}$ This case initiated a

\footnotetext{
102 Ibid. at 102.

103 Ibid. at 103.

104 Opuz, supra note 59.

105 Branko, supra note 60, and Bopkhoyeva, supra note 61.

106 Paúl, supra note 101 at 104.

107 See, also: Lucía Melgar, A 10 años de la sentencia de campo algodonero, El Economista (Nov. 11, 2019). IACtHR, Seminario: De la sentencia González y otras Vs. México ("Campo Algodonero") a la de Mujeres Victimas de Tortura Sexual en Atenco: Avances y pendientes (March 6, 2020) available at https:// werere.corteidh.or.cr/noticias.cfm. $n=14$.
} 
strong and consolidated sequence of three cases of femicide in the Americas, followed by the cases of Véliz Franco et al. v. Guatemala and Velásquez Paiz et al. v. Guatemala. In both cases, the Court analyzed every claim of the victims and the Commission. Also, it mentioned important doctrines and concepts to explain the phenomenon of violence against women, ${ }^{108}$ and it referred to statements made by expert witnesses. ${ }^{109}$

Regarding the ECOWAS Court, it can be said that its approach is like the ECtHR. For example, in the case of Mary Sunday v. The Federal Republic of Nigeria, this court limited its brief decision to the arguments of the victim, those from the State, and the performance of the authorities to declare responsibility. The tribunal did not go further to establish a general context in which the case was circumscribed, particularly the context of domestic violence in which the case was embedded.

Considering these differences among approaches, and beyond some considerations about the suitability of one approach over another, the maximalist approach is, without doubt, a powerful tool to increase awareness about femicide in different regions. Hence, the adoption of a maximalist approach is beneficial in the fight against femicide for three reasons: a) through a maximalist approach the tribunals can learn and analyze the phenomenon of femicide to guide States to eliminate it in the local sphere; $b$ ) this approach gives voice to the claims of victims and of the civil society, and shows the complex dynamics in which femicide operates in countries, and c) given the relevance of the judgments of regional courts for their regions, the jurisprudence on femicide can generate a great echo. In the case of the IACtHR, its maximalist approach has allowed this tribunal to develop specific States' obligations and reparations.

\section{The Scope of The State's Obligations}

Another important point is how these courts have developed the scope of the State's obligations. According to the analysis, the three Courts agree in all their cases that gender-based violence triggers duties in States. ${ }^{110}$ In this regard, the IACtHR has established that States have obligations to respect and to guarantee women's rights ${ }^{11}$ and the ECOWAS Court has stated that the State cannot ignore what occurs in the private sphere, especially in violations against personal integrity. ${ }^{112}$ Particularly, the duty to guarantee and its specific obligations of prevention and due diligence have been highlighted by regional courts.

\footnotetext{
108 González et al., supra note 76, at para. 143 .

109 Ibid. at para. 141.

110 Opuz, supra note 59, at para. 74.

111 González et al., supra note 76, at 61-64.

112 Mary Sunday, supra note 94, at 7.
} 
Feminicide cases have allowed regional human rights courts to explore the duty of prevention. In cases of feminicides related to domestic violence, the ECtHR frequently ascertains whether local authorities have taken preventive measures as a part of its duty to protect the victims. ${ }^{13}$ Concerning that obligation, this tribunal has also remarked the importance of determining whether if authorities were aware of a real and immediate risk to the life of the victims. ${ }^{114}$

The most important development of the scope of that duty has been led by the IACtHR. This Court has developed a double-moment standard to analyze the fulfillment of this duty according to two moments: before the victim's disappearance and before the discovery of the body. Regarding the first moment, the Court has stated that "the eventual failure to prevent the disappearance does not entail per se the international responsibility of the State because" the State does not have an "unlimited responsibility concerning any illegal act against" women and girls. ${ }^{115}$ About the second moment, it has mentioned that, in the view of the context of violence, it is important to know whether the State "was aware that a real and immediate danger existed that [the victim] would be attacked". ${ }^{116}$ In most of the cases, as a result of the reports initiated by the parents, the authorities were aware of the dangerous situations of victims, but they did not act with due diligence.

Both the ECtHR and the IACtHR have emphasized the specific duty of due diligence of States in cases of violence against women. On one hand, the ECtHR has stated that even when in the context of domestic violence victims are "intimidated or threatened into either not reporting the crime or withdrawing complaints", the State has the responsibility to "ensure accountability and guard against impunity". ${ }^{117}$ It has also added that "while a decision not to prosecute in a particular case would not necessarily be in breach of due diligence obligations, law or practice which automatically paralyzed a domestic violence investigation or prosecution where a victim withdrew her complaint would be".

On the other hand, the IACtHR has emphasized the obligation of authorities to act with due diligence during the investigative process. The Court has expressed concern about the application of gender stereotypes during the investigation of a femicide ${ }^{118}$ or a disappearance ${ }^{119}$ because it can affect the opportune adoption of measures or lines of investigation. Even though the ECOWAS Court has not explicitly mentioned diligence in its jurisprudence, in the case of Mary Sunday v. Nigeria this tribunal criticized

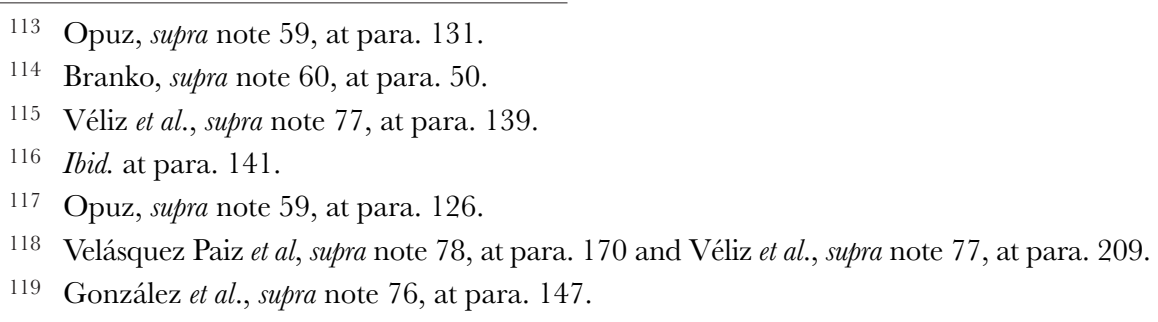


the performance of police authorities who dismissed in their police report the urgency of turning the case to the competent authorities. ${ }^{120}$

Although the ECtHR established the context of domestic violence in one of its cases, the IACtHR has paid attention to the regional situation of violence against women in all its cases. ${ }^{121}$ The establishment of contexts of gender violence is a tool used by both the ECtHR and the IACtHR, and in both cases, those Courts have adopted reports issued by NGO's and other data provided by official entities. ${ }^{122}$ However, the IACtHR is the only one that has been consistent in this practice ${ }^{123}$ of reviewing in detail the actions adopted by States to prevent gender-based violence. For instance, in all its cases about feminicide, it has established the general context of the country regarding gender-based violence, something that has helped it to determine how widespread is the duty of prevention of States in cases of feminicide. And, in some cases, the IACtHR has used the data obtained from those contexts to demand States the adoption of measures and to declare the breach of State obligations. ${ }^{124}$

\section{Reparations}

As a part of their mandates to protect and look for the reparations of human rights violations, the three courts ordered States to repair the damage. Nevertheless, there are evident differences in the way in which each court believes that it is an adequate reparation. And there is a different conception about how to avoid the repetition of those violations.

In the case of the ECtHR, this tribunal is not used to order measures beyond the payment to victims. ${ }^{125}$ Following that direction, in its cases reviewed the only measure of reparation by damages was the order for States to pay an amount of money for non-pecuniary damages. ${ }^{126}$ The position of the ECOWAS Court is similar to this feature. In consequence, it only ordered the State to make a payment for the damages suffered by the victim.

On the contrary, following its concept of integral reparation ${ }^{127}$ the IACtHR has been consistent while ordering States to adopt measures of satisfaction and guarantees of non-repetition, rehabilitation, and compensation. Accord-

\footnotetext{
120 Mary Sunday, supra note 94.

121 For example, in Opuz $v$. Turkey, the ECtHR made an exercise of comparison among laws from diverse countries in Europe. Opuz, supra note 59 at, paras. 87-90.

122 Ibid. at paras. 91 to 106.

123 The IACtHR has followed this structure in all its cases of feminicide.

124 Velásquez Paiz et al, supra note 78, at para. 133.

125 Darren Hawkins \& Wade Jacoby, Partial compliance: a comparison of the European and InterAmerican Courts of Human Rights, 6 J. InT'L L \& INT'L REL. 35, 84 (2010).

126 Branko, supra note 60, at para. 78.

127 González et al., supra note 76, at para. 450.
} 
ing to this approach, the IACtHR contributes through its measures for reparations to the transformation of all the State system to prevent the repetition of the acts and to concrete the healing of victims. The Court usually designs an exhaustive plan of reparations for victims that includes the creation of policies, ${ }^{128}$ public apologies, ${ }^{129}$ banks of data, ${ }^{130}$ among others. Particularly, the Court paid special attention to the investigation of femicides and to the design of training, institutional programs and policies to deal with violence against women in the local sphere. For example, in the three cases of femicide, the Court ordered public apologies and public acts of acknowledgment of international responsibility. ${ }^{131}$ Additionally, the Court has considered that enacting policies and programs to eliminate discriminatory socio-cultural patterns against femicide is a very important point so that States can fulfill their international obligations to protect women. ${ }^{132}$

Compared to the ECtHR and the ECOWAS Court, the consistent practice of the IACtHR and the scope of its reparations for victims of gender-based killings is by far more useful to tackle the problem of femicide in the local sphere not just for the countries who received the judgment, but also for the countries that are members of the system. It has allowed the IACtHR - in collaboration with civil society and victims who collocate the topic in the system - to use its reparations also as catalyst for the analysis of the problem, the creation of solutions and goals to end femicide.

\section{Gonclusions}

As the most extreme expression of gender-based violence and human rights violation against women, feminicide is a phenomenon that affects all regions across the world, and its acknowledgment, as well as its theoretical and legal development, are still in process. Consequently, from the human rights international law, RSHR are international platforms entitled to protect victims of femicide. Nevertheless, each regional court of human rights has adopted a particular approach to evaluate gender-based killings. Some of these diverse approaches have not been consistent in the identification of gender-based killings in their cases, as occurs with the ECtHR and the ECOWAS Court, while the IACtHR has built a strong and consistent jurisprudence on the matter, which has helped to consolidate the analysis of the phenomenon of femicide in its region. Depending on their maximalist or minimalist approach, all those tribunals have developed the scope of the States' obligations and ordered the

\footnotetext{
128 Velásquez Paiz et al, supra note 78, at para. 262.

129 Ibid. at para. 240.

130 González et al., supra note 76, at para. 512.

131 See, for example: Ibid. at para. 469; Velásquez Paiz et al, supra note 78, at para. 240, and Véliz et al., supra note 77, at para. 257.

132 Véliz et al., supra note 77, at para. 274.
} 
reparation of damages. In this regard, although the ECtHR and the IACtHR three courts have addressed specific State's obligations of prevention and due diligence, the ECOWAS Court has been shyer in this respect. However, having adopted a maximalist approach, the IACtHR has developed in a much deeper way the State obligations and the scope of reparations of victims, which has contributed to tackle the problem and to guide States to eliminate femicide in the local sphere. 